\title{
Study for anti-infective potential of antibacterial properties of Murraya Koenigii
}

\author{
Satish Chand Saini*, Dr. GBS Reddy \\ Tower G 4, Flat No. 402, Kavitadham, Phase-2, Near-Madhuram Party plot, Zadeshwar Road, Bharuch, Pin \\ Code-392012 (Gujarat) India.email ID: satishcsaini@yahoo.com, Contact No. +919879113850.
}

\begin{abstract}
In vitro antimicrobial efficacy of leaves extracts of Murraya koenigii was performed by disc diffusion method against six Gram positive bacterial (Bacillus cereus, Bacillus megaterium, Bacillus subtilis, Staphylococcus aureus, Staphylococcus epidermidis, Staphylococcus subfava), nine Gram negative bacterial (Alcaligenes fecalis, Enterobacter aerogenes, Escherichia coli, Klebsiella pneumoniae, Proteus mirabilis, Proteus vulgaris, Pseudomonas aeruginosa, Pseudomonas pseudoalcaligenes and Salmonella typhimurium) and two fungal strains (Aspergillus brasiliensis, candida albicans). The most susceptible bacterial strains were Bacillus subtilis and Staphylococcus aureus whereas not showing antifungal activity. The leaf extracts in organic solvents (methanol) showed better antimicrobial activity as compared to aqueous extracts Results of present study shows that leaves of Murraya koenigii having antimicrobial activity and can be used for natural antimicrobial agent.
\end{abstract}

Key Words: Antibacterial, antimicrobial, antifungal, curry leaves, Murraya koenigii,

\section{Introduction}

In the present scenario of emergence of multiple drug resistance to human pathogenic organisms, this has necessitated a search for new antimicrobial susbstances from other sources including plants. Traditionally used medicinal plants produce a variety of compounds of known therapeutic properties. The substances that can either inhibit the growth of pathogens or kill them and have no or least toxicity to host cells are considered candidates for developing new new antimicrobial drugs. In recent years, antimicrobial properties of medicinal plants are being increasingly reported from different parts of the world. Murraya koenigii (Rutaceae) commonly known as curry neem, is an aromatic more or less deciduous shrub or a small tree up to $6 \mathrm{~m}$ in height found throughout India up to an altitude of $1500 \mathrm{~m}$ and are cultivated for its aromatic leaves ${ }^{1}$. In traditional system of medicine, it is used as antiemetic, antidiarrhoeal, dysentery, febrifuge, blood purifier, tonic, stomachic, flavoring agent in curried and chutneys. The oil is used externally for bruises, eruption, in soap and perfume industry $^{2}$.Carbazole alkaloids ${ }^{3}$, the major constituents of the plant are known to possess cytotoxic, antioxidative, antimutagenic and anti-inflammatory activities ${ }^{4-5}$. The leaves are rich in mono-terpenoids and sesquiterpenoids which exhibited antifungal activities ${ }^{6}$. In the present investigation, an attempt has been made to investigate antimicrobial screening of aqueous and solvent leaf extracts of Murraya koenigii.

\section{Plant Collection:}

\section{Materials and methods}

Fresh leaves of Murraya koenigii were collected randomly from the semi-arid region of Himalaya's, HRDI, Dehraun-UK and other different sources of India. The taxonomic identities of these plants were confirmed by Dr. GBS Reddy Department of R\&D chemistry. Fresh plant materials were washed under running tap water, air dried and homogenized to fine powder and stored in air-tight bottles.

\section{Preparation of Plant Extracts: Aqueous Extraction:}

10 grams of dried plant material was extracted in distilled water for $6 \mathrm{~h}$ at slow heat. After every two hours it was filtered through eight layers of muslin cloth and centrifuged at $2000 \mathrm{rpm}$ for $25 \mathrm{~min}$. The supernatant was collected. This procedure was repeated twice and after $8 \mathrm{~h}$, the supernatant was concentrated to make the final volume one-fifth of the original volume. The extract was then autoclaved at $111^{\circ} \mathrm{C}$ and $15 \mathrm{lbs}$ pressure and stored at $5^{\circ} \mathrm{C}$. 


\section{Solvent Extraction:}

Twenty grams of dried leaves material was extracted with $100 \mathrm{ml}$ of ethanol/ methanol kept on a rotary shaker for $20 \mathrm{~h}$ at room temperature. Thereafter, it was filtered and centrifuged at $2000 \mathrm{rpm}$ for $20 \mathrm{~min}$. The supernatant was collected and the solvent was evaporated to make the final volume one-fifth of the original volume (Saini) et al., 2005). It was stored at $5^{\circ} \mathrm{C}$ in airtight bottles for further studies.

\section{Microorganisms used:}

The test organisms used included Gram positive bacterial cultures Bacillus cereus ATCC11778, Bacillus megaterium ATCC9885, Bacillus subtilis ATCC6633, Staphylococcus aureus ATCC25923, Staphylococcus epidermidis ATCC12228 and Staphylococcus subfava NCIM2178; Gram-negative bacterial cultures Alcaligenes fecalis ATCC8750, Enterobacter aerogenes ATCC13048, Escherichia coli ATCC25922, Klebsiella pneumoniae NCIM2719, Proteus mirabilis NCIM224, Proteus vulgaris NCTC8313, Pseudomonas aeruginosa ATCC27853, Pseudomonas pseudoalcaligenes ATCC17440 and Salmonella abony NCTC6017 and fungal cultures Aspergillus brasiliensis 16404, candida albicans 10231.

\section{Culture media and inoculum}

Sabouraud Dextrose (SD) and soyabean Casein Digest (SCD) media (Hi media) were used for fungal and bacterial cultures, respectively. Bacterial cultures, freshly grown at $37^{\circ} \mathrm{C}$ for 24 hours and fungal cultures at $28^{\circ} \mathrm{C}$ for 48 hours were appropriately diluted in sterile normal saline solution to obtain the cell suspension at $10^{5}$ $\mathrm{CFU} / \mathrm{ml}$.

All the microbial cultures were maintained at $4{ }^{\circ} \mathrm{C}$ on nutrient agar slants (for bacteria) and MGYP slants (for yeast).

\section{Preparation of test compound} of $25 \mathrm{mg} / \mathrm{ml}$.

The extracts of Muraya koenigii were diluted in 100\% dimethylsulphoxide (DMSO) and stock prepared

\section{Antimicrobial Assay:}

Antimicrobial assay of crude extracts was carried out against nine test pathogenic strains by disc diffusion $\operatorname{method}^{7}$.The Muller Hinton Agar and Sabouraud Dextrose Agar plates were inoculated with $\left(10^{6}\right.$ $\mathrm{cfu} / \mathrm{ml}$ ) of the bacterial and fungal strains respectively. The sterilized Whatman no. 1 filter paper disc of $6 \mathrm{~mm}$. were impregnated with $1000 \mu \mathrm{g} / \mathrm{ml}$ of extract and placed aseptically on the surface of inoculated plates with the help of sterile forceps. The standard discs impregnated with antibiotics nystatin $(2 \mu \mathrm{g} / \mathrm{ml})$ and chloramphenicol $(2 \mu \mathrm{g} / \mathrm{ml})$ were used as control. The plates were incubated at $37^{\circ} \mathrm{C}$ for 24 hours and at $28^{\circ} \mathrm{C}$ for 48 hours for bacteria and fungi respectively. The diameter of the zone of inhibition in $\mathrm{mm}$ was measured. The experiment was repeated three times and the mean values calculated for the conclusion.

Minimum inhibitory concentration was determined by broth dilution method ${ }^{8}$. For broth dilution, $1 \mathrm{ml}$ of the standardized suspension of the strain $\left(10^{6} \mathrm{cfu} / \mathrm{ml}\right)$ was added to each tube containing extracts at various concentrations in soyabean casein digest medium. The tubes were incubated at $37^{\circ} \mathrm{C}$ for 24 hours and at $28^{\circ} \mathrm{C}$ for 48 hours for bacteria and fungi respectively and observed for visible growth. The experiment was repeated three times. The minimum inhibitory concentration (MIC) is taken as the lowest concentration of the extracts at which there turbidity after incubation.

\section{Results and Discussion}

The antimicrobial efficacy of the leaves extracts of Murraya koenigii was determined on the basis of zone of inhibition (Table 1) and minimum inhibitory concentration (Table 2). In the present study methanol extract was found to be effective against tested microbial strains as compares to aqueous extract. Most sensitive bacteria were S. aureus and Bacillus subtilis. It shows that leaves extracts of Murraya koenigii having antimicrobial properties which are effective against diseases.

The results from the present investigation shows that leaves extracts of Murraya koenigii can be used as antimicrobial agent. Study supports traditional use of curry leaves.

\section{Conclusion}

The present investigation concludes that leaves extracts of Murraya koenigii shows antimicrobial properties which confirms the use in traditional medicines to treat the disease caused by pathogens. Methanol extracts shows maximum antimicrobial activity against Staphylococcus aureus and Aspergillus brasilliensis. 


\section{Acknowledgement}

The authors are highly thankful to the management of Herbal Research and Development Institute (HRDI),Selaqui, Dehradun (UK) India and Management of Samarth Analytical Laboratory, Nasik (MH), India for providing necessary facilities.

\section{References}

[1]. Anonymous, The Wealth of India: A Dictionary of Indian Raw Materials and Industrial Products Publication and Information Directorate, New Delhi: CSIR, 1998:446-448.

[2]. Prajapati ND, Purohit SS, Sharma AK, Kumar T.A Handbook of Medicinal Plants. Jodhpur: Agrobios, 2003: $352-353$.

[3]. Ito C, Thoyama Y, Omura M, Kajiura I and Furukawa H, Alkaloidal constituents of Murraya koenihii; isolation and structural elucidation of novel binary carbazolequinones and carbazole alkaloids, Chem Pharm Bull, 1993, 41, 2096-2100.

[4]. The Wealth of India: A Dictionary of Indian Raw Materials and Industrial Products Publication and Information Directorate, New Delhi: CSIR, Volume 6 (L-M), 1962 pp 446-448.

[5]. Chakraborty DP, Barman BK and Bose PK, On the constitution of murrayanine, apyranocarbazole derivative isolated from Murraya koenigii, Tetrahedron, 1965, 21, 681 .

[6]. Goutam MP and Purohit RM, Antimicrobial activity of the essential oil of the leaves of Murraya koenigii Spreng (IndianCurry Leaf), Indian J pharm, 1974, 36 (1), 11

[7]. Newman DJ, Cragg GM and Snader KM, Natural products as sources of new drugs over the period 1981-2002, J Nat Prod, 2003, $66,1022-1037$.

[8]. Gould JC and Bowie JH, The determination of bacterial sensitivity to antibiotics, Edinb Med J, 1952, 59, $178-199$.

Table 1- Antimicrobial activity of leaves extracts of Murraya koenigii

\begin{tabular}{|c|c|c|c|c|}
\hline \multirow[b]{2}{*}{ Test organism } & \multirow[b]{2}{*}{ Methanol Extract } & \multirow[b]{2}{*}{ Aqueous Extract } & \multicolumn{2}{|c|}{ Control } \\
\hline & & & $\begin{array}{l}\text { Nystatin } \\
(2 \mu \mathrm{g} / \mathrm{ml})\end{array}$ & $\begin{array}{l}\text { Chloramphenicol } \\
(2 \mu \mathrm{g} / \mathrm{ml})\end{array}$ \\
\hline Bacillus cereus & 8.22 & 5.25 & - & 18.67 \\
\hline Bacillus megaterium & 9.37 & 5.22 & - & 18.08 \\
\hline Bacillus subtilis & 12.39 & 10.67 & - & 17.96 \\
\hline Staphylococcus aureus & 10.64 & 8.09 & - & 20.22 \\
\hline Staphylococcus epidermidis & 9.29 & 6.61 & - & 19.87 \\
\hline Staphylococcus subfava & 7.33 & 3.19 & - & 19.00 \\
\hline Alcaligenes fecalis & 2.55 & - & - & 18.76 \\
\hline Enterobacter aerogenes & - & - & - & 20.19 \\
\hline Escherichia coli & 7.05 & 3.22 & - & 21.64 \\
\hline Klebsiella pneumonia & 7.76 & 4.13 & - & 19.08 \\
\hline Proteus mirabilis & - & - & - & 17.67 \\
\hline Proteus vulgaris & 1.68 & - & - & 18.01 \\
\hline Pseudomonas aeruginosa & 4.89 & 1.52 & - & 20.31 \\
\hline Pseudomonas pseudoalcaligenes & 3.36 & 1.08 & - & 19.63 \\
\hline Salmonella abony & 8.86 & 5.45 & - & 22.08 \\
\hline Aspergillus brasiliensis & 14.68 & 10.76 & 21.28 & - \\
\hline candida albicans & 7.16 & 3.59 & 18.67 & - \\
\hline
\end{tabular}

Zone of inhibition in mm, - : No activity, Values are average of three replicates

Table 2- Minimum Inhibitory Concentration (MIC) of leaves extracts of Murraya koenigii Values are average of three replicates

\begin{tabular}{|l|c|c|}
\multicolumn{1}{|c|}{ Test organism } & $\begin{array}{c}\text { Methanol Extract } \\
(\mathrm{mg} / \mathrm{ml})\end{array}$ & $\begin{array}{c}\text { Aqueous Extract } \\
(\mathrm{mg} / \mathrm{ml})\end{array}$ \\
\hline Bacillus cereus & 1.25 & 2.50 \\
\hline Bacillus megaterium & 1.25 & 2.50 \\
\hline Bacillus subtilis & 0.312 & 0.625 \\
\hline Staphylococcus aureus & 0.312 & 0.625 \\
\hline Staphylococcus epidermidis & 0.625 & -25 \\
\hline Staphylococcus subfava & 0.625 & - \\
\hline Alcaligenes fecalis & 2.50 & - \\
\hline Enterobacter aerogenes & - & - \\
\hline Escherichia coli & 2.50 & - \\
\hline Klebsiella pneumonia & 2.50 & - \\
\hline Proteus mirabilis & - & - \\
\hline Proteus vulgaris & - & 2.50 \\
\hline Pseudomonas aeruginosa & 1.25 & - \\
\hline Pseudomonas pseudoalcaligenes & - & - \\
\hline Salmonella abony & 1.25 & 0.625 \\
\hline Aspergillus brasiliensis & 0.312 & 2.50 \\
\hline candida albicans & 0.625 & \\
\hline
\end{tabular}

